\title{
KONFERENCE K VÝROČí NAROZENÍ JOSEFA STEPLINGA A VYDÁNÍ PRIVILEGIA CÍSAŘE MATYÁŠE PRO KLEMENTINSKOU AKADEMII
}

Ve dnech 9.-10. listopadu 2016 se v Zrcadlové kapli Klementina konala pod záštitou rektora Univerzity Karlovy, pražské primátorky a ministra kultury ČR mezinárodní konference Klementinum a jezuitská věda, pořádaná Národní knihovnou ve spolupráci s Astronomickým ústavem UK a Ústavem dějin a archivem UK. Během jednání zazněla celá řada zajímavých př́spěvků zahraničních i domácích účastníků.

Mezi jinými vystoupil např. Jean Steinauer ze Švýcarska, který hovořil o závěrečných letech působení známého ,apoštola Německa“ Petra Canisia ve Freiburgu. Jezuita Paul Mueller (vyslanec jednoho z členů organizačního výboru Paula Gabora SJ z Vatikánské astronomické observatoře) přesvědčivě popřel starší mylné soudy o zastaralosti jezuitského pojímání vědy a dodal podněty k odstranění údajných rozporů mezi naukami přírodními a humanitními. Daniela Tinková předložila vlastní koncept šíření osvícenského myšlení do střední Evropy ze Západu a navrhla periodizaci ukotvení vědeckého života v českých zemích. Hans Ullmaier z Jüllichu se soustředil především na osobnost Steplingova současníka Boškoviče, jenž krátký čas v Praze také studoval. Nijolé Bulotaitė z Vilniusu upozornila na význam zakladatele astronomické observatoře ve Vilniusu a někdejšího Steplingova žáka Tomase Žebrauskase.

Z domácích, resp. česko-slovenských badatelů připomenu především Josefa Smolku, který byl skutečným spiritus agens celého zasedání. Nejprve promluvil o osobnosti Josefa Steplinga, poté Alena Šolcová rozebrala hlavní Steplingovy práce a Martin Šolc pohovořil o astronomických pozorováních v Klementinu i o dochovaných astronomických památkách. S tím korespondoval prríspěvek Antonína Švejdy o astronomických přistrojích a pomůckách ve sbírkách Národního technického muzea v Praze. Petra Hyklová se zmínila o „druhém životě“ klementinského astronomického muzea. Tibor Morovics z Bratislavy upozornil na analogie mezi vědeckým dílem uherského jezuity Paula Makó a aktivitami Josefa Steplinga a badatelka $\mathrm{z}$ další důležité někdejš́ jezuitské univerzity v Trnavě Henrieta Žažová seznámila s dějinami tamní observatoře založené v roce 1753 . Zdislav Šíma připomenul jisté peripetie ze života jezuitských misionářů, kteří se zabývali přírodovědnými a geografickými výzkumy. Zajímavé bylo i sdělení Jakuba Halody o Steplingově pozorování meteoritů, které spadly nedaleko Tábora v roce $1753 .{ }^{1}$

1 Podrobný referát o konferenci jsem otiskla v AUC-HUCP 56/2, 2016, s. 131-132 (Konference o historické vědě). 
Bohužel se mi podařilo shromáždit jen část přednesených př́spěvků, které mohou nyní vyjít tiskem. Důvodem, proč mnozí z účastníků nakonec nedodali své texty, byly jednak jisté organizační zmatky, jednak skutečnost, že někteří nereagovali ani na opakované urgence a konečné znění svých referátů neposlali.

Ivana Čornejová 